\title{
DOES SMOKING CAUSE ORAL CANDIDA COLONIES GROWTH?
}

\author{
Sarah Mersil* \\ Department of Oral Medicine, Faculty of Dentistry \\ Universitas Prof. Dr. Moestopo (Beragama) \\ Naifadiniaulia Lailiqonita \\ Faculty of Dentistry, Universitas Prof. Dr. Moestopo (Beragama) \\ *Correspondence: sarah.m@dsn.moestopo.ac.id
}

\author{
ARTICLE INFO \\ Article History: \\ received: $12 / 10 / 2020$ \\ revised: 02/12/2020 \\ accepted: 29/01/2021 \\ Keywords: \\ smoker; smoking; candida \\ colonies growth \\ DOI:
}

\section{INTRODUCTION}

Smoking is an activity where a person is enjoying the nicotine smoke produced from the burning tobacco. This habit is an activity that we often encounter in society. Not only in Indonesia but also in the world.(Ambarwati, Ayu Khoirotul U , Fifit Kurniawati , Tika Diah K, 2014) Smoking, basically enjoying the nicotine while its burned.(Drope et al., 2018) It is one of the biggest issues causing many health problems, killing more than 7 million people per year. More than 6 million of these deaths were the result of direct tobacco use, while around 890,000 of non-smokers being exposed to secondhand smoke.(World Health Organization, 2014) Based on Riset Kesehatan Dasar (RISKESDAS) in 2018 show that the proportion of Indonesians aged 15 years and over who smoke every day around $24.3 \%$. The prevalence of smoking was higher in men $(47.3 \%)$ than in women $(1.2 \%)$. The average number of cigarettes smoked per day by smokers in Indonesia is 12.8\%.(Badan Penelitian dan Pengembangan Kesehatan, 2018)

The chemical components in cigarette smoke that has been identified reaches 4,800 types.(Drope et al., 2018) Cigarettes have amount number of active components 
that can threaten health. The active ingredient components consist of $92 \%$ gas components and $8 \%$ particle components. The toxins in cigarette smoke cause many diseases such as sudden blood clots, heart attacks and strokes which can be triggered by tobacco smoke.(Rochadi, 2005)

Smoking causes pathological changes in the oral cavity and has various systemic and oral mucosa effects. The changes in the oral mucosa are caused by the many irritants, toxins, and carcinogens found in cigarettes. Smoking increases the risk of various oral diseases such as oral cancer, leukoplakia, oral submucosa, leukoedema, oral hairy, bacterial infections, tooth staining, rhomboid glossitis, halitosis, and oral thrush.(Trandafir et al., 2011) Tobacco use also suppresses the immune system's response to oral infections.(Petersen, 2003)

The increasing number and invasiveness of oral candida colonies, causes of oral thrush, is caused by many predisposing factors, which damage to the oral mucosa. Some of the factors are smoking habits, poor oral hygiene, denture wear, hypovitaminosis, iron deficiency, pregnancy, HIV infection, diabetes mellitus and debilitated patients such as those receiving antibiotics, steroids or cytotoxic therapy.(Muzurović et al., 2013) Smoking habits can also affect oral normal flora, including candida colonies, which shows a higher level of attachment to epithelial cells. Exposure to tobacco smoke has been shown to cause microbial biofilm formation, making smokers more susceptible to lifethreatening oral infections including oral thrush. Tobacco smoke triggers an increase in the activity of oral pathogens against the host. One of them is to accelerate the activity of biofilm formation, adhesion, invasion, and infection against the host. One of the pathogens that have an effect on cigarette smoke is Candida albicans.(Semlali et al., 2014)

Study presented by Muzurovic et al. in 2013, the relationship between smoking and oral candida colonies in healthy adults in a dental clinic found that candida is the most common microorganism found in the oral cavity of smoking people, around $82.5 \%$ of all examined subjects.(Muzurović et al., 2013) However, study presented by Becker et al. in 2015, the relationship between smoking habits and oral candida showed no significant correlation and found that smoking had little effect on the growth of candida colonies compared to other factors such as dry mouth, immune deficiency disorders or antibiotic treatment.(Becker, 2015) Darwazeh A et al. 2010 also found that smoking did not increase oral candida colonies in smokers who did not have systemic disease or were taking long-term medication.(Darwazeh et al., 2010)

All those studies show that not all smokers have a high number of candida colonies in the oral cavity. The aim of this study is to prove smoking causes oral candida colonies growth. Smoking has effects which causes oral thrush. This study can be used as an educational material for oral thrush prevention, and as a source of information for patients or community groups.

\section{METHOD}

An observational analytic study. The sample of this study consisted of 15 smokers and 15 nonsmokers, oral candida colonies is taken from the oral cavity using swab method. Candida is identified using sabouraud's dextrose agar (SDA) and incubated at $37^{\circ} \mathrm{C}$ for $24-48$ hours The inclusion criteria of this study are males and 18-25 year old, without systemic disease, and not on taking long-term drugs also signs the informed consent. The exclusion criteria of this study are males who were not cooperative and who vomited while taking samples. We are asking how to maintain oral hygiene and about oral complaints that carried out using a questionnaire. Those questions are habit of brushing their tongue, using dental floss, using mouthwash, frequency of brushing their teeth twice a day, and complaints of dry mouth or xerostomia. 
Limitation of this study is a relative minority of participants. The average age of smokers in the study group was relatively low. A more varied age group might demonstrate higher expression of the oral candida counts, but old age might express diverse factors such as compromised health, prescribed medications, etc. Another limitations in terms of duration and amount of smoking may affect certain species more than others and investigating this aspect of the association between smoking and oral candida colonies growth might demonstrate valuable results.

Data were analyzed using MannWhitney test to find out whether there was a difference in the number of oral candida colonies between the smoker and nonsmoker groups.

\section{RESULT AND DISCUSSION}

Table 1 shows the average number of oral candida colonies in the smokers group are $568 \mathrm{cfu} / \mathrm{ml}$ and the average number of oral candida colonies in the nonsmokers group are $557 \mathrm{cfu} / \mathrm{ml}$. It shows the average number of oral candida colonies in the oral cavity is higher in smokers group than nonsmokers.

Table 1. Oral Candida colonies count among smokers and nonsmokers

\begin{tabular}{clcc}
\hline No & \multicolumn{1}{c}{ Groups } & $\mathrm{n}$ & $P$ Value \\
\hline 1 & Smokers & 15 & 0,820 \\
2 & Non Smokers & 15 & \\
\hline
\end{tabular}

Source: analyzed by author, 2021.
Table 2 shows the results of the MannWhitney test $\mathrm{p}$ value $=0.820$. This proves that the test results do not show a statistically significant difference between the smoker and nonsmoker groups, so it can be seen that there is no significant difference in the number of oral candida colonies between smokers and nonsmokers. The basis for the decision, if the $p$ value is $<0.05$, there is a significant difference in the number of oral candida colonies between smokers and nonsmokers and if the $p$ value is $>0.05$, there is no significant difference in the number of oral candida colonies between smokers and nonsmokers.

Table 2. Candidal colonies count among smokers compared with nonsmokers group

\begin{tabular}{cccc}
\hline No & Groups & $\mathrm{n}$ & $\begin{array}{c}\text { Number of oral candida } \\
\text { colonies }\end{array}$ \\
\hline 1 & Smokers & 15 & $568 \mathrm{cfu} / \mathrm{ml}$ \\
2 & Non Smokers & 15 & $557 \mathrm{cfu} / \mathrm{ml}$ \\
\hline
\end{tabular}

Source: analyzed by author, 2021.

Table 3 shows that as many as 9 smoker samples (60\%) have habit of brushing their tongues, followed by 7 nonsmoker samples (46.6\%). As many as 8 smoker samples (53.3\%) have habit of using dental floss, followed by 5 nonsmoker samples (33.3\%). As many as 6 nonsmokers samples (40\%) have habit of using mouthwash, followed by 3 smoker samples (20\%). As many as 15 smoker samples $(100 \%)$ have a frequency of brushing their teeth twice a day, followed by 12 nonsmoker samples (80\%). A total of 2 smoker samples(13.3\%) have complaints of dry mouth, followed by nonsmoker samples as many as 4 samples (26.6\%). 
Table 3. Maintain Oral Hygiene Habit and Oral Complaints among Smokers and Nonsmokers

\begin{tabular}{|c|c|c|c|c|c|c|c|c|c|c|}
\hline & \multicolumn{2}{|c|}{$\begin{array}{l}\text { Brushing } \\
\text { tongue }\end{array}$} & \multicolumn{2}{|c|}{ Flossing } & \multicolumn{2}{|c|}{$\begin{array}{l}\text { Using } \\
\text { mouthwash }\end{array}$} & \multicolumn{2}{|c|}{$\begin{array}{c}\text { Frequency } \\
\text { of brushing teeth }\end{array}$} & \multicolumn{2}{|c|}{ Dry mouth } \\
\hline & Yes & No & Yes & No & Yes & No & $\begin{array}{l}\text { Less than } \\
\text { twice a day }\end{array}$ & $\begin{array}{c}\text { Twice a } \\
\text { day }\end{array}$ & Yes & No \\
\hline \multirow{2}{*}{ Smokers } & 9 & 6 & 8 & 7 & 3 & 12 & 0 & 15 & 2 & 13 \\
\hline & $60 \%$ & $40 \%$ & $53,3 \%$ & $46,6 \%$ & $20 \%$ & $80 \%$ & $0 \%$ & $100 \%$ & $13,3 \%$ & $86,6 \%$ \\
\hline \multirow{2}{*}{$\begin{array}{l}\text { Non } \\
\text { smokers }\end{array}$} & 7 & 8 & 5 & 10 & 6 & 9 & 3 & 12 & 4 & 11 \\
\hline & $46 \%$ & $53,3 \%$ & $33,3 \%$ & $66,6 \%$ & $40 \%$ & $60 \%$ & $20 \%$ & $80 \%$ & $26,6 \%$ & $73,3 \%$ \\
\hline
\end{tabular}

Source: analyzed by author, 2021.

\section{Discussion}

Smoking is the habit of enjoying nicotine smoke from burning tobacco and is a habit that is very common and widespread in society.(Rochadi, 2005) The nicotine produced is a chemical substance that is addictive and causes dependence.(Kusuma et al., 2012) Candida is part of the normal flora that can be found in the oral cavity of individuals healthy with a number of $<100$ colony forming units per milliliter.(Alanazi et al., 2014; Darwazeh et al., 2010) This study is conducted to see whether smoking habits are related to the number of oral candida colonies compared to nonsmokers. Study presented by Becker T et al. 2015 on The Association Between Smoking Habit and Candida in The Oral Cavity, showed that there was no relationship between smoking and candida in the oral cavity.(Becker, 2015)

Table 1 shows the average number of oral candida colonies in the smokers group are $568 \mathrm{cfu} / \mathrm{ml}$ and the average number of oral candida colonies in the nonsmokers group are $557 \mathrm{cfu} / \mathrm{ml}$. It shows the average number of oral candida colonies in the oral cavity is higher in smokers group than nonsmokers. The average number of oral candida colonies in this study is higher than the study presented by Darwazeh A et al in 2010, which carried out oral candida taking using the concentrated oral rinse method. Darwazeh A et al showed that the average number of oral candida colonies in smokers was $333 \mathrm{cfu} / \mathrm{ml}$ and nonsmokers was 268 cfu / ml.(Darwazeh et al., 2010) This may be due to the method of taking candida in the oral cavity in this study as well. In contrast, taking oral candida in this study used a swab technique that localized to the dorsal tongue, where the candida was mostly attached to the surface of the tongue because the surface of the tongue had a rough texture that contributed to the invasion process, including involvement in adhesion, proliferation, and hyphal formation from Candida Cells.(Majima et al., 2014)

Based on the results of this study, table 2 shows that there is no significant difference in the number of oral candida colonies between smokers and nonsmokers ( $\mathrm{p}$ value $=0.820(\mathrm{p}>0.05))$, according to study presented by Becker $\mathrm{T}$ et al in 2015 where there was no significant difference in the number of candida colonies in the oral cavity between smokers and nonsmokers. In their study, Becker T et al. in 2015 also said that smoking has a small effect on the growth of candida colonies in the oral cavity, compared to other factors such as dry mouth, immune deficiency disorders or antibiotic treatment.(Becker, 2015) This study is also in accordance with study presented by Darwazeh A et al in 2010 where there was no significant relationship between smoking and the number of candida colonization in the oral cavity in smokers who did not have systemic disease 
or took long-term drugs. In their 2010 study, Darwazeh A et al. said the association between candida and tobacco smoking developed when candida carriers were present before the onset of smoking, with tobacco only contributing to increased yeast concentration by inducing changes in mucous membranes.(Darwazeh et al., 2010)

This study is different from study presented by Muzurovic S et al in 2013 in a respondent's age between 18-60 years old where smoking was significantly associated with the number of candida colonies in the oral cavity $(p<0.05)$ with the results of the number of oral candida colonies in smokers $55 \%$ and $45 \%$ non-smokers.(Muzurović et al., 2013) This might be the age of the respondents were more varied, reached 60 years, which includes extreme age which is one of the predisposing factors for candida infection due to weakened immunity.(Patil et al., 2015)

In this study, we are asking how to maintain oral hygiene such as the habit of brushing the tongue, the habit of using dental floss, the frequency of brushing teeth in one day, and also asking about complaints of dry mouth or xerostomia. Table 3 shows that $60 \%$ smokers have a habit of brushing their tongue is higher than nonsmokers, around $46.6 \%$ in 15 smokers. A habit of using dental floss, smokers are higher, around $53.3 \%$ compared to nonsmokers, around $33.3 \%$. A habit of using mouthwash, the smokers are lower, around $20 \%$ compared to nonsmokers, around 40\%. For the frequency of brushing teeth twice a day, smokers are higher, around $100 \%$ than nonsmokers, around $80 \%$. Table 3 also shows that the complaints of dry mouth or xerostomia experienced by smokers are only $13.3 \%$. Based on the questionnaires, group of smokers have maintained good oral hygiene and those who experienced complaints of dry mouth or xerostomia are only 2 out of 15 samples. Poor oral hygiene can be a good place for oral candida growth and xerostomia are a local predisposing factors for candida infection.(Patil et al., 2015) Similarly, a studied by Majima $T$ et al in 2014 provided a questionnaire on how to maintain oral and dental hygiene, such as the frequency of brushing teeth and the method of brushing teeth used.(Majima et al., 2014) It is possible that in this study is no significant difference in the number of oral candida colonies between smokers and nonsmokers because the samples on average have a good level of dental and oral hygiene and have not complaints of dry mouth or xerostomia.

\section{CONCLUSION}

In this study, smoking does not cause oral candida colonies growth. Have a good habits of maintaining oral health may control oral candida colonies growth. We wish to note that our basic findings about the early steps of prevent oral candida colonies growth in the oral cavity may suggest that frequent oral care treatment, which removes oral candida cells from this cavity, is very important for prophylaxis and avoidance of oral thrush.

\section{Acknowledgement}

We grateful for all respondents, laboratory assistants and parties who had helped in making this study.

\section{REFERENCE}

Alanazi, H., Semlali, A., Perraud, L., Chmielewski, W., Zakrzewski, A., \& Rouabhia, M. (2014). Cigarette SmokeExposed Candida albicans Increased Chitin Production and Modulated Human Fibroblast Cell Responses. BioMed Research International. https://doi.org/10.1155/2014/9631 56

Ambarwati , Ayu Khoirotul U , Fifit Kurniawati, Tika Diah K, S. D. (2014). Media Leaflet, Video dan Pengetahuan Siswa SD tentang Bahaya Merokok (Studi pada Siswa SDN 78 Sabrang Lor Mojosongo Surakarta). Kemas, 10(1), 7-13.

https://doi.org/10.1142/S0218348X 98000419 
Badan Penelitian dan Pengembangan Kesehatan. (2018). Laporan Nasional Riset Kesehatan Dasar 2018. In Badan Penelitian dan Pengembangan Kesehatan (p. 198).

Becker, T. (2015). The Association between Smoking Habits and Candida in the Oral Cavity. International Journal of Dentistry and Oral Health, 1(2). https://doi.org/10.16966/23787090.107

Darwazeh, A. M. G., Hammad, M. M., \& AlJamaei, A. A. (2010). The relationship between oral hygiene and oral colonization with Candida species in healthy adult subjects*. International Journal of Dental Hygiene, 8(2), 128133. https://doi.org/10.1111/j.16015037.2009.00407.x

Drope, J., Schluger, N., Cahn, Z., Drope, J., Hamill, S., Islami, F., Liber, A., Nargis, N., \& Stoklosa, M. (2018). The Tobacco Atlas. Atlanta: American Cancer Society and Vital Strategies. In American Cancer Society, Inc.

Kusuma, D. A., Yuwono, S. S., \& Wulan, S. N. (2012). Studi Kadar Nikotin dan Tar Sembilan Merk Rokok Kretek Filter yang Beredar di Wilayah Kabupaten Nganjuk Dani Ali Kusuma 1) , Sudarminto S. Yuwono 2) dan Siti Narsito Wulan 2) 2). Jurusan Teknologi Pertanian, 5(3), 151-155.

Majima, T., Ito-Kuwa, S., Nagatomi, R., \& Nakamura, K. (2014). Study of the oral carriage of Candida sp. in dental students and staff-Identification of Candida sp. and background survey. Oral Science International, 11(1), 3034. https://doi.org/10.1016/S13488643(13)00029-3

Muzurović, S., Hukić, M., Babajić, E., \& Smajić, R. (2013). The relationship between cigarette smoking and oral colonization with Candida species in healthy adult subjects. Medicinski Glasnik, 10(2), 397-399.

Patil, S., Rao, R. S., Majumdar, B., \& Anil, S. (2015). Clinical appearance of oral Candida infection and therapeutic strategies. Frontiers in Microbiology, 6(DEC), 1-10. https://doi.org/10.3389/fmicb.2015. 01391

Petersen, P. E. (2003). Tobacco and oral health--the role of the world health organization. Oral Health \& Preventive Dentistry, 1(4), 309-315. https://doi.org/10.3290/j.ohpd.a866 8

Rochadi, R. (2005). Berbagai Upaya Penanggulangan Perilaku Merokok di Indonesia. Jurnal Kesehatan Masyarakat USU, IX(2), 125-159.

Semlali, A., Killer, K., Alanazi, H., Chmielewski, W., \& Rouabhia, M. (2014). Cigarette smoke condensate increases C. albicans adhesion, growth, biofilm formation, and EAP1, HWP1 and SAP2 gene expression. BMC Microbiology, 14(1), 1-9. https://doi.org/10.1186/1471-218014-61

Trandafir, V., Trandafir, D., Gog, D., Popescu, E., Vicol, C., \& Burlui, V. (2011). Tobacco-Induced Oral Mucosal Modifications. Oral Pathology, 1(1), 84-91.

World Health Organization. (2014). Global Youth Tobacco Survey (GYTS): Indonesia report 2014. In Who-Searo. 